Stern, Julian ORCID:

https://orcid.org/0000-0003-4126-0100 (2017) Critical exchange: Avoiding schooling taboos: A reply to Rasmussen. Research in Education, 97 (1). pp. 30-32.

Downloaded from: http://ray.yorksj.ac.uk/id/eprint/2391/

The version presented here may differ from the published version or version of record. If you intend to cite from the work you are advised to consult the publisher's version: https://doi.org/10.1177/0034523717705460

Research at York St John (RaY) is an institutional repository. It supports the principles of open access by making the research outputs of the University available in digital form. Copyright of the items stored in RaY reside with the authors and/or other copyright owners. Users may access full text items free of charge, and may download a copy for private study or non-commercial research. For further reuse terms, see licence terms governing individual outputs. Institutional Repository Policy Statement

\title{
RaY
}

Research at the University of York St John

For more information please contact RaY at ray@yorksj.ac.uk 


\section{Avoiding Schooling Taboos: A Reply to Rasmussen}

Such an interesting piece by Rasmussen, with issues of sexuality and schooling neatly complementing issues of religion and schooling. Both sets of issues move - over time, and across cultures and countries - between public and private (and intermediate) spheres. Both challenge simple legal categories, and both generate competing, sometimes conflicting, challenges to societies, to schools and to personal identity.

In terms of identity politics, there are some who have religion or sexuality as central to their identities, others who see religion or sexuality as merely one amongst many aspects of their identities. It is good, therefore, to see a piece on the relationship of religion to schooling being couched in terms of an exploration of sexuality. As Rasmussen concludes, 'the best way forward may be found in diverse solutions to the tensions perceived between religious and sexual freedoms', and I certainly agree with that. It is no great educational improvement to make sexuality less taboo in schools if the cost of this is to make religion more taboo. I would return to my claim that inclusion in schools should involve inclusion of 'whole' people, not people stripped of central features of their identity - whether religion, sexuality, politics or any other feature.

If this makes inclusion sound like a straightforward task, then I should qualify my remarks. The literature on intersectionality stresses the complexity of interactions between sexuality, 'race', disability, class, religion, poverty, age and ... well, the list goes on. And as Cole and Gunter note, 'it is the ambiguity of intersectionality which is its strength', because 'with each new intersection, new connections emerge and previously hidden exclusions come to light' (Cole and Gunter, 2010, p 7, quoting Davis, emphasis added). There is need, as I have said, for a suitably 'messy conversation' on these issues - inevitably messy, but necessarily a conversation, a dialogue, and not what Buber refers to as a 'monologue disguised as dialogue' (Buber 2002, p 22). Let me give a concrete example. In an institution familiar to me, the students' union apparently spent four months discussing the possible design of toilets in their new building. Toilets are an interesting 'test' of inclusion. Are there separate toilets for men and women (which oversimplifies sexuality), and separate (ungendered?) toilets for those with certain disabilities? Are there culturally-sensitive toilets of different design for those brought up with different methods of toileting? And if there are 'universal' toilets, uncategorised, then how will this include those who - for reasons of religion or for the avoidance of sexual harassment - want separate toilets? There is no simple solution that satisfies all the interests, and what was finally decided upon was a compromise. And that compromise was different to the compromises made for other buildings on the same campus - the $19^{\text {th }}$ century buildings (with ungendered toilets, plus some for those with disabilities), the early $21^{\text {st }}$ century buildings (with separate men's and women's toilets, plus some for those with disabilities), and so on. Religion and sexuality affect these very concrete (and porcelain) aspects of life in schools.

The idea of the state being the arbiter of inclusion is mentioned a number of times, and as Rasmussen acknowledges this is somewhat problematic. States are modern inventions and the forms of citizenship that match state boundaries are uncertain, artificial, and rarely uncontroversial categories. In the UK as in many countries, 'citizenship education' is compulsory even for those children who are denied citizenship, and in different parts of the UK, membership of the 'united' kingdom is far from universally accepted. In Australia, the very idea of the nation was and remains a challenge - often an oppressive insult - to those people whose families were present prior to European settlement. Escaping the frying pan of religious oppression is not helping by jumping in the fire of state oppression. And it would be too easy, anyway, to see only oppression in religion. As Rasmussen says so well, 'religion' or 'a religion' 
cannot be thought of as simple unified categories. In the current century, the bigger religious divisions are not typically interreligious: they are intrareligious. Liberal Christians, Muslims, Hindus and Jews generally have more in common with each other than with conservatives from their own traditions. Putnam and Campbell describe how the political divisions in the US have changed in the half century since Kennedy overcame the barriers to being elected as a Catholic president, to a point at which politics are now associated with how religious you are, rather than the religion or denomination to which a candidate belongs (Putnam and Campbell 2010, p 2). Schools have a responsibility to teach about these and other differences - and to do so in such a way as to acknowledge diversity. (Religious education can all too often choose to teach only the 'nicest' versions of religions, leaving children - and teachers with even less of a grasp of religious reality than when they started.)

I share with Rasmussen a wish for more discussion of sexuality within the school curriculum. It is interesting to note research (e.g. Sauntson 2013) saying that LGBTI issues may be discussed more in religious education lessons than elsewhere - a good advert, I think, for tackling the all-too-often taboo issues of religion and sexuality together, precisely because they may, at times, come into conflict with each other. This completes my set of three claims: the need for a messy conversation, the need to include 'whole' people in schools, and the need to consider existentially-significant religious education. Schools are private-enough to be genuinely personal, and not merely functional; they are public-enough to be genuinely subject to external social and political requirements. We therefore need a willingness to tackle religion and to tackle sexuality that will help make better people, better communities, and perhaps even a better world.

Buber, M (2002 [1965]) Between Man and Man; London: Routledge.

Cole, B A and Gunter, H M (eds) (2010) Changing Lives: Women, Inclusion and the $P h D$; Stoke-on-Trent: Trentham.

Putnam, R D and Campbell, D E (2010) American Grace: How Religion Divides and Unites Us; New York: Simon \& Schuster.

Sauntson, H (2013) 'Sexual Diversity and Illocutionary Silencing in the English National Curriculum', Sex Education, 13:4, pp 395-408. 